\title{
Quality of life issues and occupational performance of persons with epilepsy
}

\author{
Qualidade de vida e desempenho ocupacional de pessoas com epilepsia \\ Renato Nickel', Carlos Eduardo Silvado², Francisco Manoel Branco Germiniani , Luciano de Paola², Nicolle Lucena \\ da Silveira ${ }^{4}$, Joana Rostirolla Batista de Souza ${ }^{4}$, Cassiano Robert ${ }^{4}$, Andressa Pereira Lima ${ }^{4}$, Lauren Machado Pinto ${ }^{4}$
}

\begin{abstract}
Epilepsy causes restrictions in the performance of various daily activities. The aiming of this study was to investigate whether these restrictions affect the perceived quality of Life. The assessments Quality of Life in Epilepsy-31 (QOLIE-31) and Canadian Occupational Performance Measure (COPM) were applied in a sample that consisted of a single group of 34 subjects with at least two years of uncontrolled seizures. The results indicated that the most affected domains of QOLIE-31 were seizure worry, $29.77( \pm 21.72)$, and effects of drugs, 49.75 ( \pm 28.58 ), and for the COPM, the average of performance and satisfaction were respectively $3.10( \pm 3.07)$ and $4.45( \pm 3.29)$, and performance limitations most frequently cited were maintain employment (18), left home alone (15) and courses (15). The application of the Spearman correlation coefficient showed that the three main performance limitations posed by the COPM, especially regarding the level of satisfaction, influence the perception of quality of life. Thus, occupational performance proves to be an important area of intervention with subjects with epilepsy.
\end{abstract}

Key words: activities of daily living, epilepsy, neurology, occupational therapy, quality of life, task performance and analysis.

\section{RESUMO}

A epilepsia causa limitações quanto ao desempenho de várias atividades diárias. Este estudo procurou investigar se essas limitações afetam a percepção da qualidade de vida (QV) do sujeito com epilepsia. Foram estudados 34 sujeitos com crises epiléticas não controladas há pelo menos dois anos, para os quais foram aplicadas, dentre outras, as avaliações QOLIE-31 para QV e Medida Canadense de Desempenho Ocupacional (COPM) para análise das limitações no desempenho ocupacional. Os resultados indicaram que os domínios da QOLIE-31 mais afetados foram preocupação com as crises $(29,8 \pm 21,7)$ e efeitos dos medicamentos $(49,7 \pm 28,6)$. Em relação à COPM, as médias de desem-

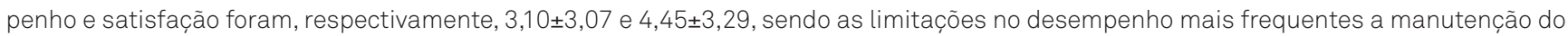
emprego (18), ser capaz de sair de casa sozinho (15) e poder frequentar cursos (15). A aplicação do coeficiente de correlação de Spearman evidenciou que as três principais limitações no desempenho levantadas pela COPM, principalmente em relação ao nível de satisfação, influenciam na percepção da qualidade de vida do sujeito com epilepsia. Dessa forma, o desempenho ocupacional provou ser uma importante área de intervenção com sujeitos epiléticos.

Palavras-Chave: atividades cotidianas, epilepsia, neurologia, terapia ocupacional, qualidade de vida, análise e desempenho de tarefas.

In spite of the many efforts of the last decades that have tried to control seizures and reduce the adverse effects of antiepileptic drugs (AEDs), epilepsy still remains a disabling disease, affecting a great number of individuals worldwide, with a rather taxing impact on any given subject's activities of daily living and, ultimately, his own quality of life (QOL) ${ }^{1}$.

According to the literature, about $70 \%$ of individuals with epilepsy have their seizures controlled by the adequate use of AEDs. However, the remaining 30\% do not respond in an adequate manner to this type of treatment and, therefore, are deemed medically resistant ${ }^{2}$. Some of those patients will be referred to a tertiary centre where they will be further investigated and either undergo evaluation for surgical treatment or be offered a palliative treatment option.

Epilepsy has a great impact in the life of patients regardless or seizure control, and a comprehensive treatment should encompass other domains, such as improvement of quality of life $^{3}$. Thus, the concept of health-related quality of life (HQOL) has been developed to assess the perceptions of family members, social issues, limitations due to having a chronic disease and health-provider/health-assistant issues ${ }^{4}$.

The aim of this study was to evaluate the limitations of occupational performance and how they influence on the perception

Hospital de Clínicas, Universidade Federal do Paraná (UFPR), Curitiba PR, Brazil.

${ }_{1}^{1}$ Professor Adjunto, Departamento de Terapia Ocupacional, Universidade Federal do Paraná (UFPR), Curitiba PR, Brazil;

${ }^{2}$ Professor Adjunto, Departamento de Clínica Médica, Disciplina de Neurologia, UFPR, Curitiba PR, Brazil;

${ }^{3}$ Médico, Departamento de Clínica Médica, Serviços de Neurologia e Centro de Terapia Intensiva Adulto, UFPR, Curitiba PR, Brazil;

${ }^{4}$ Acadêmicos de Iniciação Científica, Departamento de Terapia Ocupacional, UFPR, Curitiba PR, Brazil.

Correspondence: Renato Nickel; Avenida Lothário Meisner 632 / Bloco Didático II; 80210-170 Curitiba PR - Brasil; E-mail: rnickel@ufpr.br

Conflict of interest: There is no conflict of interest to declare.

Received 11 April 2011; Received in final form 19 September 2011; Accepted 26 September 2011 
of the quality of life of epileptic patients, particularly those who remain with their seizures without control despite the use of AEDs.

\section{METHODS}

We performed a descriptive, exploratory, transverse analysis of a group of 34 individuals that had been attending regularly the outpatient clinic at the Hospital de Clínicas da Universidade Federal do Paraná (HC-UFPR), or, conversely, who had been admitted to the Neurological ward during the period of the study, from $1^{\text {st }}$ November 2008 to $31^{\text {st }}$ March 2009. All of them had medically refractory epilepsy, i.e. seizures uncontrolled despite adjustment of AEDs treatment.

Subjects were assessed for quality of life by answering the Quality of Life in Epilepsy-31 (QOLIE-31) ${ }^{5}$ and for occupational performance by the Canadian Occupational Performance Measure (COPM) ${ }^{6}$.

For analysis of the COPM, the results were measured as scores from 0 to 10 both for the level of performance and the individual's personal satisfaction with his/her performance.

Data specifically related to the seizures were also collected and included the age of the subject at the time of the first seizure, duration of epilepsy, seizure frequency in the last 180 days and screening for depressive symptoms by answering the Beck Depressive Inventory.

All data was collect through individual interview by one of the investigators. For the subject to be included in the study, he or she should be older than 16 years of age, had to be medically refractory for at least two years and had to have read and sign to the written consent to participate in the study. Patients were excluded if they did not fulfill those criteria or if they had any other medical condition that would in itself interfere with their occupational performance. The study was approved by the local Human Research Ethics Committee.

As for the statistical analysis, normal distribution of variables was initially assessed, followed by subsequent correlation studies. In order to measure the relation between the limitation in performance found in the COPM and the overall result of the QOLIE-31, three different models of regression analysis were created, one for each of the following domains: additive, multiplicative and for individual evaluation of variables.

\section{RESULTS}

Out of the 34 subjects, 21 of them were female. Mean age at the time of the study was $32.9 \pm 11.9$ years of age and educational level, as measured in years of formal education, had a mean value of $9.4 \pm 4.4$ years. As for civil status, $50 \%$ of the subjects were married, $44 \%$ were single and $6 \%$ were formally divorced.

Professional occupation/employment status varied broadly, as demonstrated in Table 1.
There were many seizure types, classified according to the ILAE classification, but, for the purposes of this study, seizures were either classified as having a focal onset or as primarily generalized. Thus, 21 patients had focal onset seizures, whereas 13 subjects had primarily generalized seizures. Mean age at seizure onset was 10.6 \pm 9.9 , and the mean seizure frequency for the last 180 days immediately prior to the study was of $26.6 \pm 13.4$.

We found that the domain that was mostly affected and that had a greater impact on the subjects' quality of life was worrying about having a seizure, while the domain that had the least impact on QOL was the measure of QOL (Table 2).

Following application of the COPM, a total of 104 instances in which performance was impaired were obtained. Conversely, three subjects reported no limitations whatsoever.

Performance levels were assessed by giving a score for each individual domain/activity, ranging from 1 to 10, both for the activity itself and for the satisfaction provided by performing it. Mean values were 3.1 \pm 3.1 for performance and $4.4 \pm 3.3$ for satisfaction with performance.

Descriptive analysis showed that the limitations of performance were mostly related to being able to remain in a stable job (as reported by 18 subjects), being able to go out of home all by oneself, as well as attending educational courses, as reported by 15 subjects. Other activities were spread over several different domains and were less reported individually, as can be seen in Table 3.

Following statistical analysis of normal distribution of numerical variables, only frequency of seizures and duration of

Table 1. Subjects' current occupational status.

\begin{tabular}{lcc} 
Current occupation & Frequency & $\%$ \\
\hline Formally employed & 11 & 32.4 \\
Autonomous/self-employed & 3 & 8.8 \\
Student & 4 & 11.8 \\
Housewife & 5 & 14.7 \\
Retired & 5 & 14.7 \\
Unemployed (health-related) & 3 & 8.8 \\
Other & 3 & 8.8 \\
\hline
\end{tabular}

Table 2. Results from the QOLIE-31 evaluation.

\begin{tabular}{lc} 
Domains & Sample results (median) \\
\hline Worried about having seizures & $29.7 \pm 21.7$ \\
QOL índex & $56.7 \pm 22.8$ \\
Emotional stability & $53.5 \pm 21.4$ \\
Energy/Fatigue & $52.3 \pm 21.7$ \\
Cognition & $50.4 \pm 21.8$ \\
Drug-related side effects & $49.7 \pm 28.9$ \\
Social functioning & $54.4 \pm 28.9$ \\
Total & $51.5 \pm 17.2$ \\
Global health & $58.2 \pm 26.7$
\end{tabular}

QOLIE-31: Quality of Life in Epilepsy-31. 
seizures had a distribution that did not conform to the normal model of distribution.

Variables with a normal distribution were correlated among themselves by using Pearson's correlation coefficient,

Table 3. List of desired activities or complaints identified by the subjects, following evaluation with the COPM.

\begin{tabular}{|c|c|c|}
\hline Complaints & Frequency & $\%$ \\
\hline Being able to ride a bike & 2 & 1.92 \\
\hline Being able to catch a bus unaided & 3 & 2.88 \\
\hline Learning & 3 & 2.88 \\
\hline Taking care of the house & 2 & 1.92 \\
\hline Getting a girlfriend & 1 & 0.96 \\
\hline Social activities & 3 & 2.88 \\
\hline Going out for a walk & 1 & 0.96 \\
\hline Personal care/grooming & 1 & 0.96 \\
\hline Driving & 3 & 2.88 \\
\hline Writing & 1 & 0.96 \\
\hline Sports & 2 & 1.92 \\
\hline Going out to shop & 2 & 1.92 \\
\hline Crocheting/knitting & 3 & 2.88 \\
\hline Taking care of finances & 1 & 0.96 \\
\hline Independence in domestic activities & 2 & 1.92 \\
\hline Clothes-washing & 1 & 0.96 \\
\hline Reading & 2 & 1.92 \\
\hline Keeping a job & 18 & 17.31 \\
\hline Staying home alone while taking care of the baby & 1 & 0.96 \\
\hline Swimming & 1 & 0.96 \\
\hline Fishing & 1 & 0.96 \\
\hline Being able to attend educational courses & 15 & 14.42 \\
\hline Looking out for a job & 4 & 3.85 \\
\hline Active recreation & 1 & 0.96 \\
\hline Calm recreation & 1 & 0.96 \\
\hline Being able to go out of home alone & 15 & 14.42 \\
\hline Heating up/ cook up a meal (using the oven) & 6 & 5.77 \\
\hline Dressing & 1 & 0.96 \\
\hline Being able to travel alone & 5 & 4.81 \\
\hline Visiting friends & 1 & 0.96 \\
\hline Going back to school & 1 & 0.96 \\
\hline Total & 104 & $100 \%$ \\
\hline
\end{tabular}

COPM: Canadian Occupational Performance Measure. and the non-normal variables were assessed with Spearman's correlation coefficient.

Table 4 illustrates the correlations between the variables that had statistical significance.

As for variables with a non-normal distribution, only duration of seizure had a low and negative correlation with the QOLIE-31 following Spearman's correlation coefficient ( $\mathrm{p} \leq 0.05$ ).

Spearman's test was also used to assess the relation between the mean performance and satisfaction levels for the main domains (remaining in a stable job, being able to attend educational courses and being able to go out of home alone) with the total means of the QOLIE-31. The results are demonstrated in Table 5.

The use of different statistical models, such as regression tests, additive tests, multiplication and cross-referencing the individual variables with the three main performance limitations, as expressed by the subjects at the COMP, showed that only being able to go out of home alone had a statistically significant correlation with the subject's own satisfaction score ( $\mathrm{p} \leq 0.01)$. The other two - remaining at a stable job and being able to attend educational courses - had no statistical significance when compared with the two co-variables (satisfaction and performance scores) in a regression model. As for the mode of distribution, the values obtained in the QOLIE-31 had a normal distribution, whereas those obtained with the COPM had a non-normal distribution.

Therefore, we concluded that the satisfaction scores related to individual performance for the domains in which the subjects reported a greater limitation had a greater correlation with the results obtained in the QOLIE-31. Thus, the greater the limitation of performance, the greater the influence on the individual's own perception of quality of life.

\section{DISCUSSION}

Limitations in daily activities and social restrictions were found among the studied subjects and were similar to

Table 4. Pearson's correlation coefficient and statistical significance between variables with a normal distribution in relation to the QOLIE-31.

\begin{tabular}{lcccc}
\hline QOLIE 31 & Age & Formal Education & Beck Depression Inventory & COPM Satisfaction \\
\hline Pearson's Correlation & $-0.344^{\star}$ & $0.352^{\star}$ & $-0.487^{* *}$ & $0.483^{* *}$ \\
Sig. (2- tailed) & 0.046 & 0.041 & 0.003 & 0.004 \\
N & 34 & 34 & 34 & 34
\end{tabular}

*Correlation is significant at the 0.05 level (2-tailed); ${ }^{*}$ Correlation is significant at the 0.01 level (2-tailed); QOLIE-31: Quality of Life in Epilepsy-31; COPM: Canadian Occupational Performance Measure.

Table 5. Results of the Spearman's Correlation testing.

\begin{tabular}{lccc} 
& Remaining at the job & Able to leave home alone & Able to attend courses \\
\hline Satisfaction score & 0.47 & 0.50 & 0.24 \\
Performance score & 0.35 & 0.06 & 0.35 \\
\hline
\end{tabular}


previous reports, in which, in spite of all the pharmacological advances in the treatment of epilepsy over the last decades, social complaints, especially those related to ADL, are usually reported by patients.However, a single epidemiological, multicentre study by Marinas et al. ${ }^{7}$ had surprisingly opposite results. The aim of that study was to analyse the social inclusion of 872 adults with epilepsy and it was found that $58 \%$ of the subjects had performance scores similar to those found in the general population. It was then put in question how such disparate findings could be justified. We propose that the International Classification of Functioning, Disability and Health (ICF) ${ }^{8}$ shed some light on the possibilities.

The ICF, created by the World Health Organization (WHO), goes beyond the somewhat limited paradigm of taking into account only the health condition of any given individual and its immediate objective/consequences, it also encompasses other factors, such as environmental factors (barriers and facilitators) and personal subjective factors (age, gender, sexual preference, cultural level, etc.), that might influence on the overall health status of the individual.

According to Salgado and Souza ${ }^{9}$, it is not the disease itself that determines the individual's QOL, but rather the way that the individual lives his/her life while being affected by a chronic disease. Uncontrolled epileptic seizures lead to severe social limitations in the daily living of patients, with restrictions in family, educational, vocational and leisure activities, thus having a direct negative impact on the QOL of the person with epilepsy.

Other factors may influence the vulnerability and/or fragility status of the person with epilepsy. The report of the III Semana Nacional de Epilepsia ( $3^{\text {rd }}$ National Epilepsy Week $)^{10}$ corroborates this as it showed that the paradigm of having a chronic health condition and also the lack of knowledge about epilepsy among the general population were restrictive factors in the performance of patients with epilepsy and their activities of daily living, including being able to remain in a stable job, being able to attend educational courses and being able to go out of home alone.

Difficulty to keep one's job (code d8451 of the ICF) was the limitation most frequently reported in our study. In his study, Borge ${ }^{11}$ reported that epilepsy affects the ability of the individual to perform their job, regardless of trade, and that acceptance in the working community is a major factor in social integration, economics and individual satisfaction; therefore, limits to job stability will have a negative subjective perception of the individual's own QOL. Moreover, Parfene et al. ${ }^{12}$ demonstrated that stigma associated to epilepsy is also a restrictive factor both to job acquisition and maintenance. This is why only a handful of individuals report having epilepsy in job interviews or upon admission. However, once the individual starts having seizures during working hours and is no longer able to hide his health problem, remaining at the job becomes virtually impossible for the majority, with the individuals getting a discharge on terms of low productivity, being unable to achieve established and proposed goals or some other technical justification.

Attending an educational course was the second most reported desired activity in our population (code d825 in the ICF), which has a straight correlation with the individual's capability of obtaining and keeping a job. Once again, according to Borges et al. ${ }^{13}$, the subject's restrictions to attending a course may be related to low job qualification and with the level of education of the individual ${ }^{11}$, making it even harder for the person with epilepsy to get a formal job.

Finally, the third most common complaint reported was being unable to go out of home unattended, classified in the ICF as being able to go to different places (code d460). This factor leads to loss of independent mobility and this subsequently hampers the individual's capacity of doing daily activities and further deteriorates their quality of life.

In conclusion, our data, as well as those reported in the literature, show that limitations of activities of daily living and restrictions of social inclusion have a negative impact in the quality of life of persons with epilepsy. These factors should be carefully considered in the overall, multidisciplinary treatment of these patients, in order to cater for all their needs. An ideal multidisciplinary team should include occupational therapists to act as facilitators in the management of the individual patients activities of daily living.

A more comprehensive treatment must go beyond the limits imposed by hospital/office walls and consider that, even if the patient's seizures remain uncontrolled, they should be offered a mean by which they can perform their activities of daily living with sufficient independency, being, if possible, reintegrated into society by obtaining a job, attending courses and going about unattended.

\section{References}

1. Lám J, Rózsavölgyi M, Soós G, Vincze Z, Rajna P. Quality of life of patients with epilepsy (Hungarian survey). Seizure 2001;10:100-106.

2. Girolinet BMP. A intercambialidade entre equivalentes terapêuticos da lamotrigina: avaliação clínica e laboratorial dos pacientes portadores de epilepsia refratária [Mestrado]. Ribeirão Preto: Faculdades de Ciências Farmacêuticas de Ribeirão Preto, Universidade de São Paulo; 2009.

3. Phabphal K, Geater A, Limapichart K, Satirapunya P, Setthawatcharawanich S. Quality of life in epileptic patients in Southern Thailand. J Med Assoc Thai 2009;92:762-769.

4. Zanni KP, Bianchin MA, Marques LHN. Qualidade de vida e desempenho ocupacional de pacientes submetidos à cirurgia de epilepsia.J Epilepsy Clin Neurophysiol 2009;15:114-117.

5. Silva TI, Ciconelli RM, Alonso NB, et al. Validity and reliability of the Portuguese version of the quality of life in epilepsy inventory (QOLIE31) for Brazil. Epilepsy Behav 2007;10:234-241.

6. Law M, Baptiste S, Carswell A, et al. Medida Canadense de Desempenho Ocupacional (COPM). $1^{\text {a }}$ ed. Belo Horizonte: UFMG; 2009.

7. Marinas A, Elices E, Gil-Nagel A, et al. Socio-occupational and employment profile of patients with epilepsy. Epilepsy Behav 2011;3:223-227. 
8.

Organização Mundial da Saúde, CIF: Classificação Internacional de Funcionalidade, Incapacidade e Saúde [Centro colaborador da Organização Mundial da Saúde para Família de Classificações Internacionais, org.; Coordenação de tradução Cassia Maria Buchalla]. São Paulo: Editora da Universidade de São Paulo, 2003.

9. Salgado PCB, Souza EA. Impact of epilepsy at work: evaluation of quality of live. Arq Neuropsiquiatr 2002;60:442-445.

10. Fernandes PT, Souza RJ, Li ML. Relatório da III Semana Nacional de Epilepsia.J Epilepsy Clin Neurophysiol 2005;11:205-207.
11. Borges MA, De Marchi NS, Sato AK, Aleixo FV, Cordeiro JA. [Epileptic syndromes and seizures and their relationship with work: a propective ambulatory study in 412 epileptic patients]. Arq Neuropsiquiatr 2000;58:691-697.

12. Parfene C, Stewart TL, King TZ. Epilepsy stigma and stigma by association in workplace. Epilepsy Behav 2009;15:461-466.

13. Borges MA, Cordeiro JA, Delgado AS. [Duration and age range of epilepsy and its correlation with work: prospective ambulatory study in 379 epileptics]. Arq Neuropsiquiatr 2000;58:288-291. 